\title{
ROLE OF DIFFERENT CRITERIA IN OUTCOME ANALYSIS OF MANAGEMENT OF GAP NON-UNION
}

\section{Dr Nirjhar Maji*}

Consultant Orthopaedics Surgeon, District Hospital, Asansol. W.b. India-713301. * Corresponding Author

ABSTRACT Back ground and objectives: Gap or Defect non-union is not uncommon in Orthopaedic practice. Management involves prolonged periods of tedious procedures and decision making. The endpoint of such management does not reveal itself as a well-defined point. Follow ups must include some analysable outcome which should have a standardised criteria-based endpoint. A well-aligned, painless, noninfected, and functional limb is the goal of treatment.The objective of this study is to understand the role of different criterion to understand whether the goal has been reached.

Summary: The study is designed as retrospective, prospective observational study. It is conducted in tertiary care hospital (MIOT Hospitals, Chennai). Initial evaluation of all cases were done by Maurizio Catagni's Classification. Type of surgeries, time spent in hospital, union time were calculated. Patients were followed up for a period of lyear. Patients with average defect size of $6.29 \mathrm{~cm}$ on an average underwent 4.47 procedures and for an overall time of 17.8 weeks with around $83.80 \%$ of individuals were able to return to their preinjury activity level. Analysis of the outcome was done by ASAMI bone criteria, ASAMI functional criteria, Cattneo et al criteria and Karstrom-Olerud's functional evaluation criteria for lower limbs at onset of treatment, 6 months and 1 year of treatment.

\section{KEYWORDS :Outcome analysis, Gap or Defect nonunion, Catagni, ASAMI,Karlström-Olerud's, Cattneo}

\section{INTRODUCTION}

Gap non-union is characterized by loss of segment of long bone. The ends of the fragments may be viable but bone union across the defect is impossible. As time passes the fragments become atrophic. Catagni ${ }^{[1]}$ classified Gap Non-union into different categories by length of gaps and presence of infection.

\section{MAURIZIO CATAGNI'S CLASSIFICATION}

Al- Non infected mobile non-union

A2- Non infected stiff hypertrophic non-union without deformity

A3- Non infected Hypertrophic non-union with deformity

B1- Non infected non-union with bone defect of up to $5 \mathrm{~cm}$.

B2- Non infected non-union with bone defect exceeding $5 \mathrm{~cm}$.

B3- Non infected non-union exceeding $10 \mathrm{~cm}$ with local scarring

$\mathrm{Cl}$-Infected non-union with atrophy

C2-Infected non-union with hypertrophy without deformity

C3- Infected non-union with hypertrophy and deformity

C4- Infected non-union with bone gap of less than $5 \mathrm{~cm}$.

C5- Infected non-union with bone gap between 5 and $10 \mathrm{~cm}$.

C6- Infected non-union with bone gap exceeding $10 \mathrm{~cm}$.

Defect or Gap non-union concerns type B, C3, C4 and C5 and are subject of the study.

\section{Aim of Study}

This study aims to understand the role of different criteria in analysis of outcome of Gap non-union treated by different methods at tertiary level trauma centre.

\section{Review of Literature}

Different criteria were developed at different times for ascertaining whether an outcome is acceptable and to categorise them, separating actual success from the failures.

Association For The Study And Application Of The Methods Of Ilizarov (ASAMI) ${ }^{[2] .}$ Table 1

\begin{tabular}{|l|l|l|}
\hline Bone result & Excellent & $\begin{array}{l}\text { Union, no infection, deformity }<7^{\circ}, \\
\text { limb length discrepancy }<2.5 \mathrm{~cm}\end{array}$ \\
\hline Good & $\begin{array}{l}\text { Union + any two of the following: no } \\
\text { infection, deformity }<7^{\circ}, \text { limb length } \\
\text { discrepancy }<2.5 \mathrm{~cm}\end{array}$ \\
\hline
\end{tabular}

\begin{tabular}{|l|l|l|}
\hline & Fair & $\begin{array}{l}\text { Union +only one of the following: no } \\
\text { infection, deformity }<7^{\circ}, \text { limb length } \\
\text { discrepancy }<2.5 \mathrm{~cm}\end{array}$ \\
\hline & Poor & $\begin{array}{l}\text { Non-union } / \text { refracture } / \text { union }+ \\
\text { infection }+ \text { deformity }>7^{\circ}+\text { limb } \\
\text { length discrepancy }>2.5 \mathrm{~cm}\end{array}$ \\
\hline $\begin{array}{l}\text { Functional } \\
\text { results }\end{array}$ & Excellent & $\begin{array}{l}\text { Active, no limp, minimum stiffness } \\
\text { (loss of }<15^{\circ} \text { knee } \\
\text { extension } /<15^{\circ} \text { dorsiflexion of ankle), } \\
\text { no reflex sympathetic dystrophy, } \\
\text { insignificant pain }\end{array}$ \\
\hline & Food & $\begin{array}{l}\text { Active with one or two of the } \\
\text { following: Limp, stiffness, RSD, } \\
\text { significant pain. }\end{array}$ \\
\hline & $\begin{array}{l}\text { Active with three or all the following: } \\
\text { Limp, stiffness, RSD, significant pain }\end{array}$ \\
\hline & $\begin{array}{l}\text { Inactive (unemployment or inability to } \\
\text { return to daily activities because of } \\
\text { injury) }\end{array}$ \\
\hline & Failure & amputation \\
\hline
\end{tabular}

As ASAMI protocol does not consider bone union obtained after bone grafting as excellent, patients who had excellent result was considered to have a good result.

Cattneo et al scoring system Table 2

\begin{tabular}{|l|l|}
\hline Union: & \\
\hline U0: & Failure to obtain union \\
\hline UI: & Solid union \\
\hline Infection: & Unchanged infection \\
\hline I0: & Persistent minimal drainage \\
\hline Il: & $\begin{array}{l}\text { Complete clinical remission } \\
\text { of infection }\end{array}$ \\
\hline I2: & Invalid function \\
\hline Function: & $\begin{array}{l}\text { Able to perform all daily } \\
\text { activity }\end{array}$ \\
\hline F0: & Complete recovery \\
\hline Fl:
\end{tabular}

Karlström-Olerud's functional evaluation criteria used.for lower limbs ${ }^{[3]}$ Table 3

\begin{tabular}{|l|l|l|}
\hline Parameters & Score & \\
\hline Pain (6 months) & Severe pain & 1 point \\
\cline { 2 - 3 } & Moderate pain & 2 points \\
\hline
\end{tabular}




\begin{tabular}{|c|c|c|}
\hline & None & 3 points \\
\hline \multirow[t]{3}{*}{ Walking difficulties } & Significant / limping & 1 point \\
\hline & Moderate & 2 points \\
\hline & None & 3 points \\
\hline \multirow[t]{3}{*}{ Climbing difficulties } & Impossible & 1 point \\
\hline & With supports & 2 points \\
\hline & None & 3 points \\
\hline \multirow{3}{*}{$\begin{array}{l}\text { Difficulties during sport } \\
\text { activities }\end{array}$} & Impossible & 1 point \\
\hline & Some sports & 2 points \\
\hline & None & 3 points \\
\hline \multirow[t]{3}{*}{ Working restrictions } & Impossible & 1 point \\
\hline & Moderate & 2 points \\
\hline & None & 3 points \\
\hline \multirow[t]{3}{*}{ Skin status } & Ulcer / fistula & 1 point \\
\hline & Skin discoloration & 2 points \\
\hline & Normal & 3 points \\
\hline \multirow[t]{3}{*}{ Deformities } & $\begin{array}{l}\text { Significant over } 7 \\
\text { degrees }\end{array}$ & 1 point \\
\hline & Low up to 7 degrees & 2 points \\
\hline & None & 3 points \\
\hline \multirow{3}{*}{$\begin{array}{l}\text { Muscle atrophy / Tibial } \\
\text { circumference }\end{array}$} & $>2 \mathrm{~cm}$ & 1 point \\
\hline & $1-2 \mathrm{~cm}$ & 2 points \\
\hline & $<1 \mathrm{~cm}$ & 3 points \\
\hline \multirow{3}{*}{$\begin{array}{l}\text { Lower-limb-length } \\
\text { difference }\end{array}$} & $>2 \mathrm{~cm}$ & 1 point \\
\hline & $1-2 \mathrm{~cm}$ & 2 points \\
\hline & $<1 \mathrm{~cm}$ & 3 points \\
\hline \multirow{3}{*}{$\begin{array}{l}\text { Knee-joint motion range } \\
\text { limitation }\end{array}$} & $>20$ & 1 point \\
\hline & $10-20$ & 2 points \\
\hline & $<10$ & 3 points \\
\hline \multirow{3}{*}{$\begin{array}{l}\text { Subtalar -joint motion } \\
\text { range limitation }\end{array}$} & $>20$ & 1 point \\
\hline & $10-20$ & 2 points \\
\hline & $<10$ & 3 points \\
\hline \multirow{2}{*}{$\begin{array}{l}\text { Capacity of full } \\
\text { weightbearing }\end{array}$} & Yes & 1 point \\
\hline & No & 2 points \\
\hline
\end{tabular}

Points are given and added up based on the above criteria.

Results are evaluated as follows. 36 points: excellent, 35-33 points: good, 32-30 points: acceptable, 29-27 points: moderate, and 26-24 points: poor.

\section{Materials and Methods}

Materials

- Study design: Retrospective-Prospective Observational Study

- Retrospective - cases in different phases of ongoing management i.e. with established gap nonunion or undergoing treatment or in follow-up

- Prospective-enrolled at the onset e.g. following RTA, etc.

- Observational- No interventional measures are taken for the sake of the study.

Sample size- 105

\section{Calculation of sample size}

Calculation of the sample size was done with nMASTER software with study done by Miller ${ }^{[4]}$ et al 2010

Hypothesis Testing for Single Proportion

Population Proportion Po $=.60$

Sample Proportion $\mathrm{Pa}=.46$

Power $(\%)=80$

Alpha Error $(\%)=5$

Sided $=2$
Sample size (n) $=97$

\begin{tabular}{|c|c|c|}
\hline Alpha Error(\%) & Power(\%) & Sample Size(n) \\
\hline \multirow{3}{*}{1} & 70 & 119 \\
\cline { 2 - 3 } & 80 & 145 \\
\cline { 2 - 3 } & 90 & 185 \\
\hline \multirow{3}{*}{5} & 70 & 76 \\
\cline { 2 - 3 } & 80 & 97 \\
\cline { 2 - 3 } & 90 & 130 \\
\hline \multirow{2}{*}{10} & 70 & 58 \\
\cline { 2 - 3 } & 80 & 76 \\
\cline { 2 - 3 } & 90 & 106 \\
\hline
\end{tabular}

Setting-tertiary care hospital (MIOT hospitals, Chennai)

Duration of Study-APRIL, 2014 to OCTOBER, 2015.

\section{Recruitment of cases}

Total number recruited in their follow-up period- 86 patients.

Total number recruited on their treatment period- 19 patients.

\section{Inclusion Criteria}

All patients

- in the age range 15 to 60 years

- with segmental gap of bone of more than $1 \mathrm{~cm}$.

\section{Exclusion Criteria}

Patients with

- irregular follow-ups and poor compliance

- distal neuro-vascular deficit

- substance abuse (alcohol, illicit drugs etc.)

\section{Follow-up}

The follow-up interval was Monthly and as required and follow-up period was l year.

\section{Methodology}

Pre-operative protocol

All recruited cases were classified by Maurizio Catagni's Classification and each surgery recorded and complications documented.

\section{Statistics}

Data collection techniques

Data was collected from the OPD and IPD.

\section{Data analysis plan}

Data was tabulated and statistically analysed in MS Excel and SPSS 17 (Chicago, Illinois).

Paired sample " $\mathrm{t}$ " test was done to compare the group means and the p value was calculated.

Probability value less than 5\% was considered as statistically significant.

\section{Observations}

Table 4

CATAGNIO TYPE

\begin{tabular}{|ll|r|r|r|r|}
\hline & & Frequency & Percent & Valid Percent & $\begin{array}{c}\text { Cumulative } \\
\text { Percent }\end{array}$ \\
\hline Valid & B1 & 12 & 11.4 & 11.4 & 11.4 \\
& B2 & 41 & 39.0 & 39.0 & 50.5 \\
& B3 & 15 & 14.3 & 14.3 & 64.8 \\
& C4 & 6 & 5.7 & 5.7 & 70.5 \\
& C5 & 29 & 27.6 & 27.6 & 98.1 \\
C6 & 2 & 1.9 & 1.9 & 100.0 \\
& Total & 105 & 100.0 & 100.0 & \\
\hline
\end{tabular}

Catagnio type B2 e.i. non-infected gap-nonunion with gaps of 5 to $10 \mathrm{~cm}$ was the major group with 39 percent of cases. All 
type $\mathrm{C}$ cases were infected.

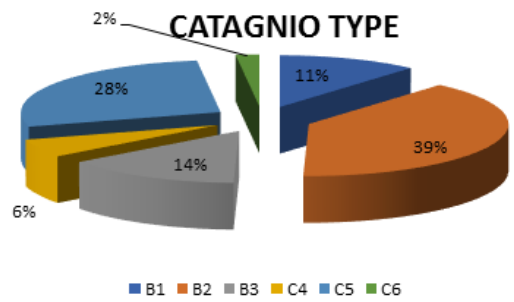

Figure 1

Table 5

\begin{tabular}{|c|c|c|c|c|c|}
\hline & $\mathrm{N}$ & Minimum & Maximum & Mean & Std. Deviation \\
\hline AGE & 105 & 16 & 56 & 30.58 & 9.281 \\
\hline LENGTH OF GAP-CM & 105 & 1.80 & 14.00 & 6.2905 & 2.31731 \\
\hline DEFORMITY- DEGREES & 105 & O & 30 & 4.81 & 8.958 \\
\hline SHORTENING-CM & 105 & .0 & 9.0 & 1.070 & 2.2316 \\
\hline TOTAL NUMBER OF PROCEDURES DONE & 105 & 2 & 10 & 4.47 & 1.582 \\
\hline TOTAL STAY IN HOSPITAL DAYS & 105 & 13 & 49 & 27.23 & 10.054 \\
\hline UNION TIME-MONTHS & 89 & 3 & 7 & 4.15 & 1.173 \\
\hline Karlström-Olerud's functional SCORE AT ADMISSION & 72 & 13 & 16 & 14.92 & 1.084 \\
\hline Karlström-Olerud's functional SCORE 8 MONTHS & 72 & 24 & 36 & 31.69 & 4.161 \\
\hline Karlström-Olerud's functional SCORE 1 YEAR & 72 & 24 & 36 & 32.37 & 3.747 \\
\hline \begin{tabular}{|l} 
Valid N (listwise) \\
\end{tabular} & 63 & & & & \\
\hline
\end{tabular}

Results

Table 6

\begin{tabular}{|l|l|l|l|l|}
\hline & 3 month & $3-6$ month & $6-9$ months & No Union \\
\hline Radius & 9 & 5 & 1 & 2 \\
\hline Ulna & 3 & 1 & 0 & 2 \\
\hline Humerus & 3 & 3 & 0 & 3 \\
\hline Femur & 6 & 11 & 1 & 3 \\
\hline Tibia & 11 & 35 & 0 & 6 \\
\hline
\end{tabular}

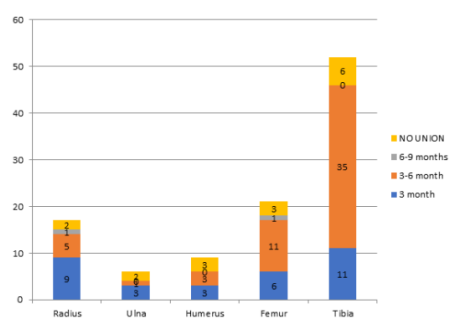

Figure 2

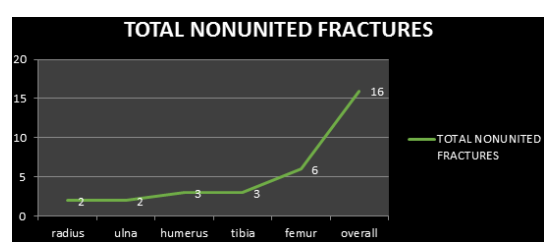

Figure 3

Table 6

\begin{tabular}{|l|l|}
\hline Number Of Procedures & Number of patients \\
\hline 2 & 1 \\
\hline 3 & 37 \\
\hline 4 & 28 \\
\hline 5 & 11 \\
\hline 6 & 8 \\
\hline 7 & 18 \\
\hline$>7$ & 1 \\
\hline
\end{tabular}

28 percent of the cases underwent procedures 4 times and only one patient underwent more than 7 procedures.

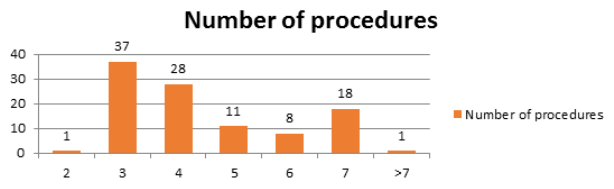

Figure 4
The average hospital stay was 27.23days, maximum stay being 49 days and minimum being 13 days.

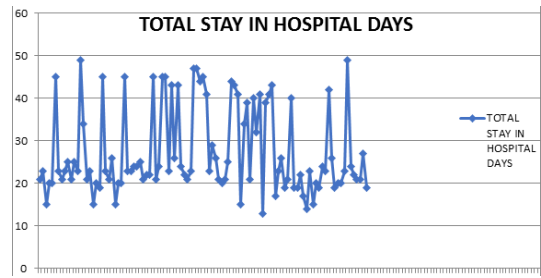

Figure 5

Stiffness was the commonest complication seen in 30 cases with Reflex sympathetic dystrophy seen in only 2 cases.

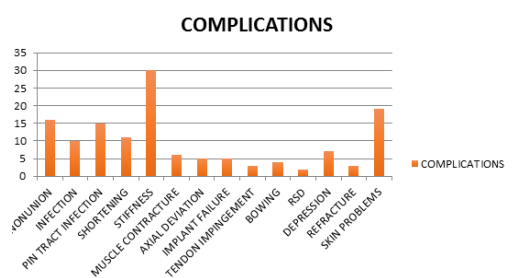

Figure 6

Analysis of results

ASAMI Bone score comparison at Onset , 6 months and 1 year

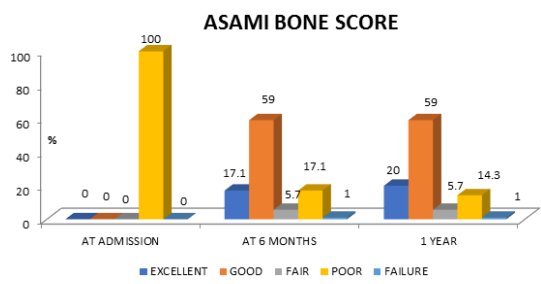

Figure 7

ASAMI BONE SCORE AT ADMISSION * ASAMI BONE SCORE AT 6 MONTHS

Table 7

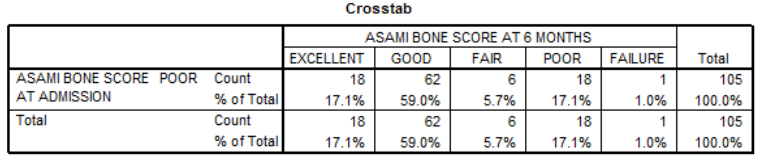

ASAMI BONE SCORE AT ADMISSION * ASAMI BONE SCORE 1 YEAR

Table 8

\begin{tabular}{|c|c|c|c|c|c|c|c|}
\hline \multicolumn{8}{|c|}{ Crosstab } \\
\hline & & \multicolumn{5}{|c|}{ ASAMI BONE SCORE 1 YEAR } & \multirow[b]{2}{*}{ Total } \\
\hline & & EXCELLENT & GOOD & FAIR & POOR & FAILURE & \\
\hline \multirow{2}{*}{$\begin{array}{l}\text { ASAMI BONE SCORE POOR } \\
\text { AT ADMISSION }\end{array}$} & Count & 21 & 62 & 6 & 15 & 1 & 105 \\
\hline & $\%$ of Total & $20.0 \%$ & $59.0 \%$ & $5.7 \%$ & $14.3 \%$ & $1.0 \%$ & $100.0 \%$ \\
\hline \multirow[t]{2}{*}{ Total } & Count & 21 & 62 & 6 & 15 & 1 & 105 \\
\hline & $\%$ of Total & $20.0 \%$ & $59.0 \%$ & $5.7 \%$ & $14.3 \%$ & $1.0 \%$ & $100.0 \%$ \\
\hline
\end{tabular}

Table 9

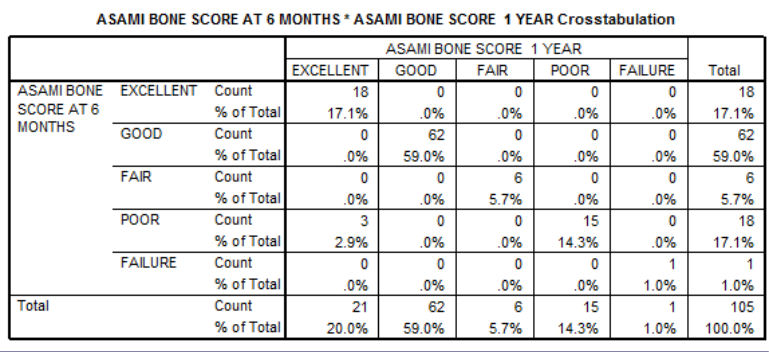


Table 10

Chi-Square Tests

\begin{tabular}{|l|r|r|r|} 
& \multicolumn{1}{|c|}{ Value } & \multicolumn{1}{c|}{ df } & $\begin{array}{c}\text { Asymp. Sig. } \\
\text { (2-sided) }\end{array}$ \\
\hline Pearson Chi-Square & \multicolumn{1}{|c|}{$390.000^{\mathrm{a}}$} & 16 & .000 \\
Likelihood Ratio & 218.734 & 16 & .000 \\
Linear-by-Linear & 77.451 & 1 & .000 \\
Association & 105 & & \\
N of Valid Cases & & \\
\hline
\end{tabular}

a. 20 cells $(80.0 \%)$ have expected count less than 5 . The minimum expected count is .01

The ASAMI bone score was Excellent in $17.1 \%$ of cases in 6 months and 20 percent of cases in 1 year. As ASAMI does not consider bone grafting as Excellent so many of the cases had to be categorized into Good. Percentage of Good was 62 at both 6 months and lyear. Values were statistically significant with $P$ value less than 0.05 . One case was a failure as it has undergone amputation following recurrence of tumour.

ASAMI Functional score comparison at Onset, 6 months and 1 year

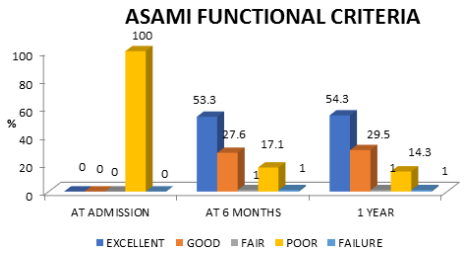

Figure 8

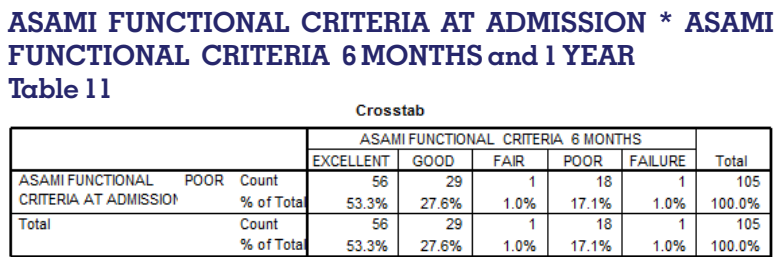

ASAMI FUNCTIONAL CRITERIA AT ADMISSION * ASAMI FUNCTIONAL CRITERIA I YEAR

Table 12

\begin{tabular}{|c|c|c|c|c|c|c|c|}
\hline & \multicolumn{5}{|c|}{ ASAMI FUNCTIONAL CRIIERIA 1 YEAR } & \multirow[b]{2}{*}{ Total } \\
\hline & & EXCELLENT & GOOD & FAIR & POOR & FAILURE & \\
\hline \begin{tabular}{|l} 
ASAMII FUNCTIONAL \\
\end{tabular} & Count & 57 & 31 & 1 & 15 & 1 & 105 \\
\hline CRITERIA AT ADMISSION & $\%$ of Tota & $54.3 \%$ & $29.5 \%$ & $1.0 \%$ & $14.3 \%$ & $1.0 \%$ & $100.0 \%$ \\
\hline Total & Count & 57 & 31 & 1 & 15 & 1 & 105 \\
\hline
\end{tabular}

Crosstabs

Table 13

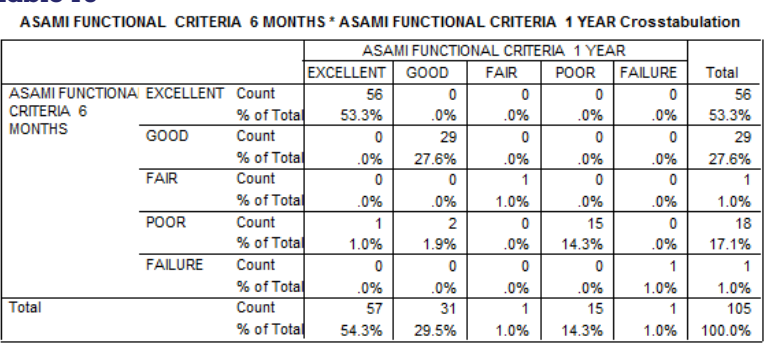

Table 14

Chi-Square Tests

\begin{tabular}{|l|r|r|r|}
\hline & \multicolumn{1}{|c|}{ Value } & df & $\begin{array}{c}\text { Asymp. Sig. } \\
\text { (2-sided) }\end{array}$ \\
\hline Pearson Chi-Square & $394.739^{\mathrm{a}}$ & 16 & .000 \\
Likelihood Ratio & 202.236 & 16 & .000 \\
Linear-by-Linear & 91.330 & 1 & .000 \\
Association & 105 & & \\
N of Valid Cases & & & \\
\hline
\end{tabular}

a. 18 cells $(72.0 \%)$ have expected count less than 5 . The minimum expected count is .01
The ASAMI functional score was Excellent in $53.3 \%$ of cases in 6 months and 54.3 percent of cases in 1 year. Percentage of Good was 27.6 and 29.5 at 6 months and lyear respectively. Cross tabulation values were statistically significant with $P$ value less than 0.05

Cattneo comparison at Onset, 6 months and 1 year

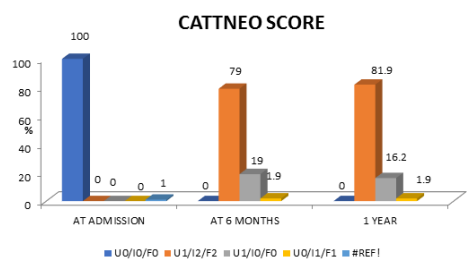

Figure 9

Cattneo SCORE AT ADMISSION * Cattneo SCORE AT 6 MONTHS

Table 15

\begin{tabular}{|c|c|c|c|c|c|}
\hline \\
\hline & & \multicolumn{3}{|c|}{ Cattneo SCORE AT 6 MONTHS } & \multirow[b]{2}{*}{ Total } \\
\hline & & U1//2/F2 & $\mathrm{U} 0 / 11 / \mathrm{F} 0$ & $\mathrm{U} 0 / 11 / \mathrm{F} 1$ & \\
\hline \multirow{2}{*}{$\begin{array}{l}\text { Cattneo SCORE U0/I0/F0 } \\
\text { AT ADMISSION }\end{array}$} & Count & 83 & 20 & 2 & 105 \\
\hline & $\%$ of Total & $79.0 \%$ & $19.0 \%$ & $1.9 \%$ & $100.0 \%$ \\
\hline \multirow[t]{2}{*}{ Total } & Count & 83 & 20 & 2 & 105 \\
\hline & $\%$ of Total & $79.0 \%$ & $19.0 \%$ & $1.9 \%$ & $100.0 \%$ \\
\hline
\end{tabular}

Cattneo SCORE AT ADMISSION * Cattneo SCORE 1 YEAR Table 16

\begin{tabular}{|c|c|c|c|c|c|}
\hline \multicolumn{6}{|c|}{ Crosstab } \\
\hline & & \multicolumn{3}{|c|}{ Cattneo SCORE 1 YEAR } & \multirow[b]{2}{*}{ Total } \\
\hline & & $\mathrm{U} 1 / / 2 / \mathrm{F} 2$ & U0/11/F0 & $\mathrm{U} 0 / 11 / \mathrm{F} 1$ & \\
\hline Cattneo SCORE U0/10/F0 & Count & 86 & 17 & 2 & 105 \\
\hline AT ADMISSION & $\%$ of Total & $81.9 \%$ & $16.2 \%$ & $1.9 \%$ & $100.0 \%$ \\
\hline Total & $\begin{array}{l}\text { Count } \\
\% \text { of Total }\end{array}$ & $\begin{array}{r}86 \\
81.9 \% \\
\end{array}$ & $\begin{array}{r}17 \\
16.2 \% \\
\end{array}$ & $\begin{array}{r}2 \\
1.9 \% \\
\end{array}$ & $\begin{array}{r}105 \\
100.0 \% \\
\end{array}$ \\
\hline
\end{tabular}

Crosstabs

Table 17

Cattneo SCORE AT 6 MONTHS * Cattneo SCORE 1 YEAR Crosstabulation

\begin{tabular}{|c|c|c|c|c|c|c|}
\hline & & & \multicolumn{3}{|c|}{ Cattneo SCORE 1 YEAR } & \multirow[b]{2}{*}{ Total } \\
\hline & & & U1//2/F2 & U0/11/F0 & U0/11/F1 & \\
\hline \multirow{6}{*}{$\begin{array}{l}\text { Cattneo SCORE } \\
\text { AT } 6 \text { MONTHS }\end{array}$} & U1//2/F2 & Count & 83 & 0 & 0 & 83 \\
\hline & & $\%$ of Total & $79.0 \%$ & $.0 \%$ & $.0 \%$ & $79.0 \%$ \\
\hline & $\mathrm{U} 0 / 11 / \mathrm{F} 0$ & Count & 3 & 17 & 0 & 20 \\
\hline & & $\%$ of Total & $2.9 \%$ & $16.2 \%$ & $.0 \%$ & $19.0 \%$ \\
\hline & $\mathrm{U} 0 / 11 / \mathrm{F} 1$ & Count & 0 & 0 & 2 & 2 \\
\hline & & $\%$ of Total & $.0 \%$ & $.0 \%$ & $1.9 \%$ & $1.9 \%$ \\
\hline \multirow{2}{*}{\multicolumn{2}{|c|}{ Total }} & Count & 86 & 17 & 2 & 105 \\
\hline & & $\%$ of Total & $81.9 \%$ & $16.2 \%$ & $1.9 \%$ & $100.0 \%$ \\
\hline
\end{tabular}

Table 18

\section{Chi-Square Tests}

\begin{tabular}{|c|c|c|c|}
\hline & Value & df & $\begin{array}{c}\text { Asymp. Sig. } \\
\text { (2-sided) }\end{array}$ \\
\hline Pearson Chi-Square & $191.137^{a}$ & 4 & .000 \\
\hline Likelihood Ratio & 95.174 & 4 & .000 \\
\hline $\begin{array}{l}\text { Linear-by-Linear } \\
\text { Association }\end{array}$ & 90.618 & 1 & .000 \\
\hline $\mathrm{N}$ of Valid Cases & 105 & & \\
\hline
\end{tabular}

a. 6 cells $(66.7 \%)$ have expected count less than 5 . The minimum expected count is 04 .

The Cattneo score was U1/I2/F2 (solid union with no infection and full function) was seen in $79 \%$ of cases in 6 months and $81.9 \%$ of cases in 1 year. Cross tabulation values were statistically significant with P value less than 0.05 .

Karlström-Olerud's functional evaluation criteria at admission, 6 months and lyear

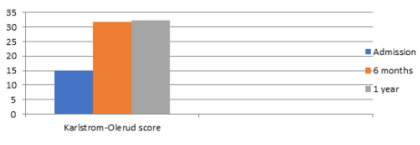

Figure 10 
Table 19

Paired Samples Statistics
\begin{tabular}{|ll|r|r|r|r|}
\hline & & \multicolumn{1}{|c|}{ Mean } & \multicolumn{1}{c|}{ N } & Std. Deviation & $\begin{array}{c}\text { Std. Error } \\
\text { Mean }\end{array}$ \\
\hline Pairr & Karlström-Olerud's functional SCORE AT ADMISSION & 14.92 & 72 & 1.084 & .128 \\
1 & Karlström-Olerud's functional SCORE 6 MONTHS & 31.69 & 72 & 4.161 & .490 \\
Pair & Karlström-Olerud's functional SCORE AT ADMISSION & 14.92 & 72 & 1.084 & .128 \\
2 & Karlström-Olerud's functional SCORE 1 YEAR & 32.38 & 72 & 3.747 & .442 \\
Pairr & Karlström-Olerud's functional SCORE 6 MONTHS & 31.69 & 72 & 4.161 & .490 \\
3 & Karlström-Olerud's functional SCORE 1 Y YEAR & 32.38 & 72 & 3.747 & .442 \\
\hline
\end{tabular}

Table 20

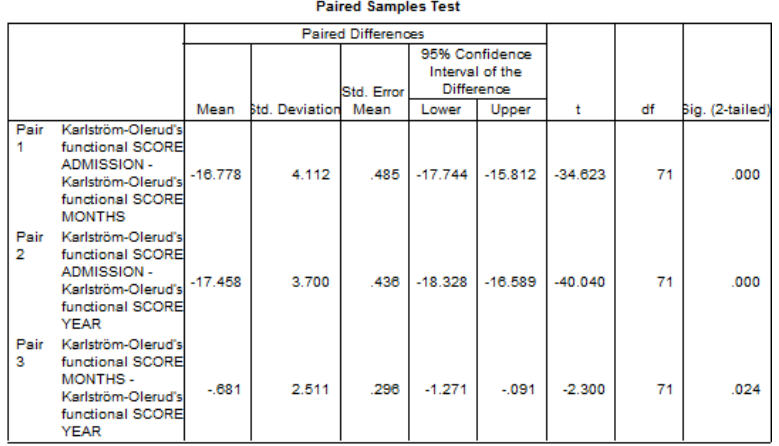

Karlström-Olerud's functional evaluation criteria for lower limbs (femur and tibia gaps) score was 14.92 at admission, 31.69 at 6 months and 32.38 at 1 year. Cross tabulation values were statistically significant with P value less than 0.05 .

Overall return to profession percentage was $83.80 \%$ of study population.

Table 21

\begin{tabular}{|l|l|l|l|}
\hline Previous profession & Number & Return to job & Percentage \% \\
\hline
\end{tabular}

\begin{tabular}{|l|l|l|l|}
\hline BUSINESSMAN & 9 & 9 & 100 \\
\hline CHEF & 2 & 1 & 50 \\
\hline CLERK & 8 & 7 & 87.5 \\
\hline DOCTOR & 1 & 1 & 100 \\
\hline DRIVER & 5 & 4 & 80 \\
\hline FARMER & 2 & 2 & 100 \\
\hline HOUSEWIFE & 4 & 3 & 75 \\
\hline MANUAL WORKER & 9 & 7 & 77.7 \\
\hline NURSE & 1 & 0 & 0 \\
\hline POLICE & 4 & 3 & 75 \\
\hline SALESMAN & 5 & 5 & 100 \\
\hline SHOPKEEPER & 9 & 7 & 77.7 \\
\hline SOFTWARE & 4 & 3 & 75 \\
\hline SOLDIER & 5 & 5 & 100 \\
\hline STUDENT & 19 & 17 & 89.47 \\
\hline SUPERVISOR & 7 & 6 & 85.71 \\
\hline
\end{tabular}

\begin{tabular}{|l|l|l|l|}
\hline TEACHER & 6 & 5 & 83.33 \\
\hline WHITE COLLAR & 5 & 3 & 60 \\
\hline
\end{tabular}

\section{DISCUSSION}

According to the Catagnio's classification, among the non infected cases 12 (11.4\%) patients were B-1, 41 (39.0\%) were B2 $(15.2 \%)$ and $15(14.3 \%)$ were B3 nonunions. Among the infected cases 6 (5.7) were C4, 29(27.6) were C5, and 2 (1.9\%) was C5.

The bone defect was calculated. The average bone defect was $6.29 \mathrm{~cm}$, which is comparable to other reports.

The average time of union in our patients was 4.15 months (Range 3 to 7 months) which was also comparable to other studies.

The treatment goal could be achieved in 89 out of 105 patients $(84.76 \%)$

The ASAMI criteria defines unemployment as poor result.

Majority of our patients (83.8\%) were able to join their previous work.

Other studies have highlighted that patient satisfaction is more important than the employment status in functional status assessment. This is not true in case of developing countries like India, where no financial support system exists for the unemployed.

According to final ASAMI scoring, the bone results were Excellent in 21 (20\%), Good in 62 (59\%), Fair in 6 (5.7\% \%), and Poor in $15(14.3 \%)$ patients.

Some of the excellent results were considered to be Good because ASAMI does not consider bone grafting as excellent result.

According to final ASAMI scoring, the functional results were Excellent in 57 (54.3\%), Good in 31 (29.5\%), Fair in 1 (1\%), and Poor in 15 (14.3\%) patients.

The Cattneo score was U1/I2/F2 (solid union with no infection and full function) was seen in $79 \%$ of cases in 6 months and $81.9 \%$ of cases in 1 year.

The lower limb patients were additionally evaluated according to Modified Functional Evaluation System by Karlstrom-Olerud. The score was 14.92 at admission, 31.69 at 6 months and 32.38 at 1 year.

\section{COMPARISON OF DIFFERENT STUDIES. Table 22}

\begin{tabular}{|c|c|c|c|c|c|c|c|c|c|c|}
\hline \multirow[t]{2}{*}{ Study } & \multirow{2}{*}{\begin{tabular}{|l|} 
Sample \\
Size
\end{tabular}} & \multicolumn{4}{|c|}{ Bone Results (\%) } & \multicolumn{5}{|c|}{ Functional Results (\%) } \\
\hline & & Excellent & good & fair & poor & Excellent & good & fair & poor & Return to work (\%) \\
\hline Dendrinos $^{[5]}$ et al 1995 & 27 & 50 & 28 & 4 & 18 & 26 & 41 & 15 & 18 & 82 \\
\hline Sangkaew C 2004 & 21 & 81 & 14.3 & 0 & 4.7 & 85.7 & 14.3 & 0 & 0 & 90 \\
\hline Sahibzada $^{[6]}$ AS et al 2005 & 20 & 60 & 10 & 15 & 15 & 35 & 40 & 20 & 5 & 85 \\
\hline Md.Shabir ${ }^{[7]}$ et al 2010 & 32 & 56 & 22 & 6 & 16 & 63 & 19 & 9 & 9 & 72 \\
\hline Our study & 105 & 20 & 59 & 5.7 & 14.3 & 54.3 & 29.5 & 1 & 14.3 & 83.80 \\
\hline
\end{tabular}

\section{Conclusion}

It is essential to use evaluation criteria for outcome analysis of 30 year old presented to the casualty with open injury of leg and ankle.

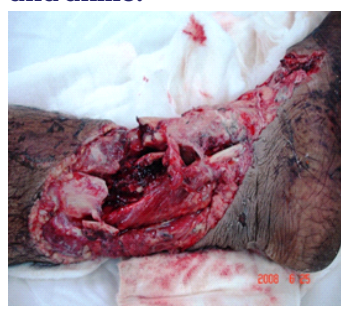

success or failure of gap nonunion management. Proper analysis of outcome is necessary for completion of treatment.

CASE PHOTOGRAPHS
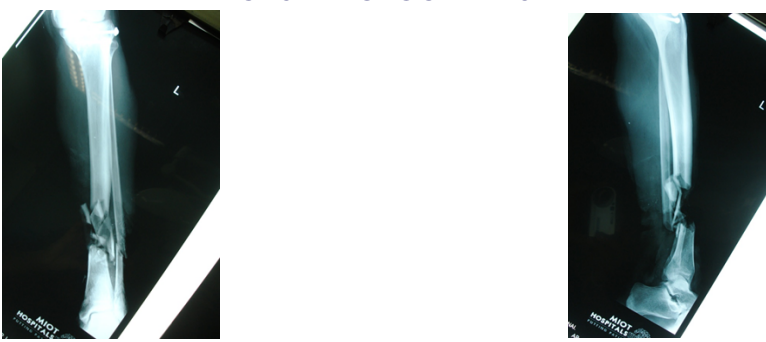
X-ray showed comminution and bone loss
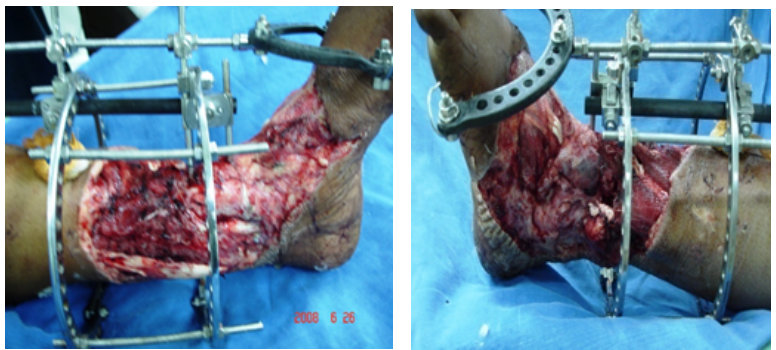

Initial stabilisation was done with ankle spanning Hybrid fixator after debridement

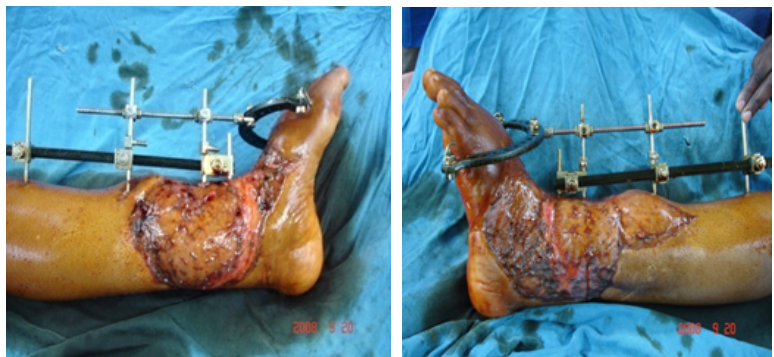

Ring fixator was converted into $\mathrm{AO}$ fixator and flap coverage was done.

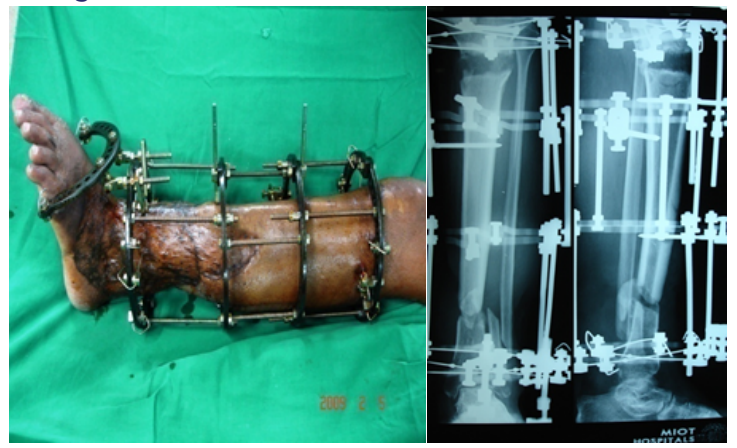

Segment transport was started with Ring fixator

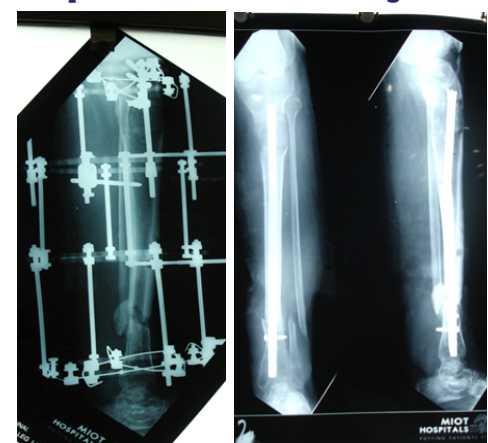

After 2 months of transport the fixator was removed and regenerate stabilised with Intramedullary nail.

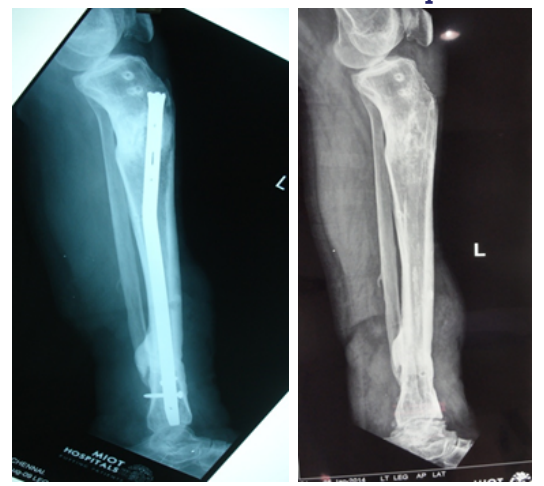

Nail was removed after the union was achieved

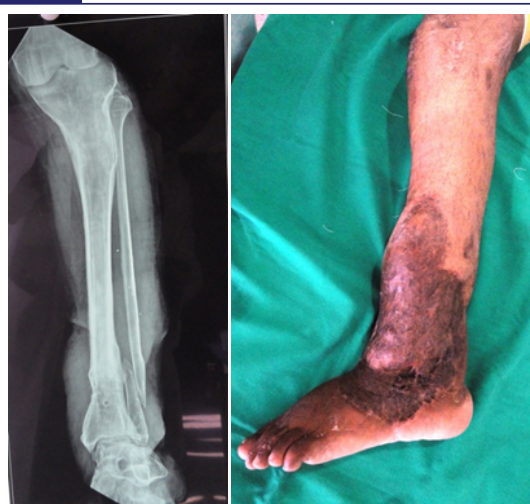

Fully functional limb with some stiffness of ankle was achieved in 7 months

\section{REFERENCES}

1. Catagni, 1991. Classification of nonunion and treatment. Milan: Medi Surgical; 1991.

2. A.S.A.M.I Group: operative principles of Ilizarov.1991

3. Karlström-Olerud's functional evaluation criteria BMC Musculoskeletal Disorders 10(1):7 • January 2009.

4. Miller et al. The repair of defects of the radius with fibular bone grafts JBJS 1947.

5. Dendrinos GK, Kontos S, Lyritsis E: Use of the Ilizarov technique for treatment of non-union of the tibia associated with infection. J Bone Joint Surg Am 1995

6. Sahibzada AS et al 2005 Management of nonunion of humeral fractures Archives of Orthopaedics and Trauma Surgery. Jan2011, Vol 131.

7. Md.Shabir Management of infected nonunion of long bones- Int Orthop, 2008 Aug;32. 